International Journal for Crime, Justice and Social Democracy

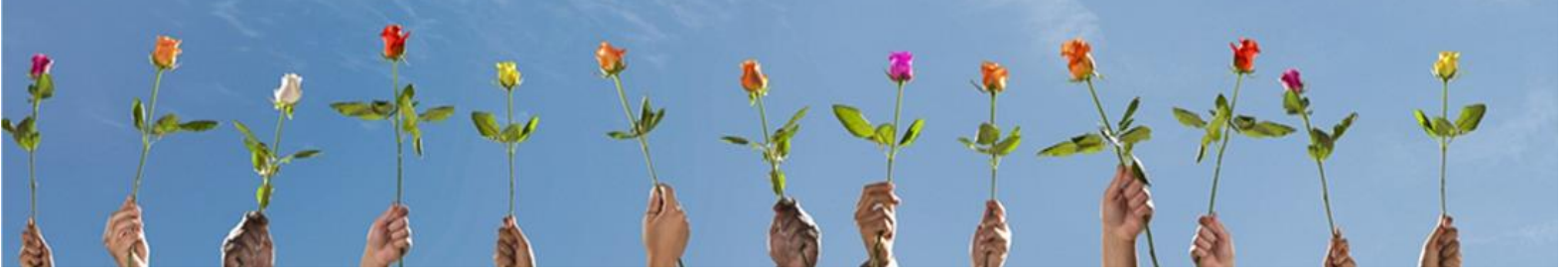

\title{
In the Dark, All Art Dealers Are Grey: Discretion and Rationalisation in the Munch Art Market
}

\author{
Siv Rebekka Runhovde \\ Norwegian Police University College, Norway
}

\begin{abstract}
In high demand among collectors worldwide, the art of expressionist painter Edvard Munch has been the object of numerous criminal incidents. This article examines to what extent these crimes have had any regulatory effect on contemporary trade in Munch's work and what precautionary measures Norwegian dealers take to prevent illicit art from entering the market. Consistent with a grey market paradigm, interviews with art dealers indicate that the trade in Munch has become tainted with risk due to the presence of many unprovenanced works in the market, yet most art dealers have narrow, preconceived ideas of the 'typical' art crime offender. Interested parties would not expect questions of provenance to be answered, so they do not ask, and social relationships are used to excuse a lack of due diligence, conveniently allowing the industry to thrive.
\end{abstract}

\section{Keywords}

Illicit art trade; grey markets; Edvard Munch; due diligence; risk.

Please cite this article as:

Runhovde SR (2021) In the dark, all art dealers are grey: Discretion and rationalisation in the Munch art market. International Journal for Crime, Justice and Social Democracy 10(2): 1-14. https://doi.org/10.5204/ijcisd.1619

Except where otherwise noted, content in this journal is licensed under a Creative Commons Attribution 4.0 International Licence. As an open access journal, articles are free to use with proper attribution. 


\section{Introduction}

In 2012, when Edvard Munch's pastel on cardboard version of Scream (1895) was sold by the New Yorkbased auction house Sotheby's (2012) for USD\$119.5 million, it became the most expensive painting ever sold at auction at the time. The seller was a named Norwegian businessman yet, as is customary, the identities of the eight bidders and the final buyer were not disclosed. In 2016, the same auction house sold Munch's Girls on the Bridge (1902) for USD \$54.5 million (Sotheby's 2016). On this occasion, no information was revealed about the seller, but that the painting was 'property from a distinguished collection'. The clandestine nature of the fine arts market distinguishes it from other marketplaces since much of the art trade remains confidential, allowing buyers and sellers to transact both indirectly and anonymously (Brodie 2014a; Coslor 2016). Illicit markets are known to capitalise on the vulnerabilities of trade systems (Bichler, Bush and Malm 2015) and there is wide concern that the level of discretion and lack of transparency within the art market makes it susceptible to criminal exploitation (Brodie 2014a, 2014b; Flynn 2016; Mackenzie 2005, 2009, 2011). In essence, crimes involving art (or art crimes) are 'criminally punishable acts that involve works of art' and include damage, theft, deception or a combination of such activities (Conklin 1994, 3). Associated types of crime are extortion and the use of art in money laundering 1 (Purkey 2010). The primary driver for art theft and forgery is the commercialisation of cultural objects as economic commodities (Burnham 1975; Durney and Proulx 2011; Kerr 2016).

Annually, a substantial number of artworks disappear in Norway, often from private residences (Didriksen 2014). One way for stolen (or otherwise illicit) art to (re)gain its financial value is to enter the art market (McLeave 2003). While art thieves typically target pieces that are difficult to identify and that can easily be sold (Bailey 2004), the extent of crime involving Edvard Munch's art in Norway is noteworthy, given the art's financial value, recognisable motifs and the publicity commonly resulting from such crimes. An analysis of what steps Norwegian dealers take to prevent illicit art from being traded (i.e., factors that influence the feasibility of disposing illicit art by Munch and other artists on the open market) could help to explain the level of criminal targeting and provide strategies for prevention. First comes an introduction to the mechanisms of the art market, followed by an account of criminality related to Munch's art. Next is a description of the data collection, before presenting the findings, detailing factors such as provenance, discretion and trust. The discussion centres on dealers' notions of risk, criminal stereotypes and accountability, before the conclusion.

\section{Literature Review}

\section{Framing the Secondary Art Market}

The first or primary art market is the initial point of sale after the creation of a work of art, directly from the artist to the customer or through a dealer. The secondary art market is where art re-enters the market after an initial sale, perhaps through an auction house (Chappell and Polk 2014). The international literature reveals that in the late twentieth century, there were several high-profile cases involving auction houses that brought the illicit trade in cultural property to the forefront of news and academic discussion (Alderman 2007) - thus, shattering the glittering myth of arts dealer propriety around the world (Brodie 2014a; Gruber 2013; Watson 1997). Reputable auction houses were found to have cooperated with smugglers to obtain and auction off antiquities (Rostomian 2002). In 2000, a scandal about price-fixing in the auction industry shifted public scrutiny from several houses' involvement in the illicit antiquities trade to potential violations of antitrust laws (Mason 2005). Regularly, dealers, collectors, auction houses and museums are the subject of complaints about their involvement in trading illicit cultural and archaeological goods (Mackenzie and Yates 2017). On this basis, scholars studying the illicit trade in antiquities reject the common assumption that the market is composed of 'legitimate' and 'illegitimate' dealers, and instead see the trade as one 'grey market' where flows of licit and illicit objects are intermixed. The supposedly clean public trade is thus tainted 'grey' by the flow therein of illicit objects (Bowman 2008; Brodie 2011; Mackenzie 2011; Mackenzie and Davis 2014). Market actors tend to refer to 'the legitimate market' (the 'white' market) as being separate from the market in illegitimate objects (the 'black' market), and present a picture of an honest trade whose reputation is damaged by criminals engaged in a parallel but separate enterprise. In the black-market paradigm, illicit trade is the domain of underground private 
sales: if the so-called legitimate trade is found to be involved it is either because the dealer was a 'bad apple' or because he was deceived (Mackenzie and Yates 2017, 73). Also, the origin of stolen goods can be concealed by creating a new origin or by claiming that an object comes from an established collection (Brodie 1999; Elia 1995). This transformation from illicit to licit status of objects is another reason why the antiquities market is considered an ambiguous grey market (Bowman 2008). The following discussion will help to determine the extent to which the Norwegian art market deserves the 'grey' label.

Preventing the onward sale of stolen or forged art partly depends on having knowledge of the origin of an object and how it has passed between previous owners (Korsell et al. 2006). In its simplest terms, 'provenance' is the historical record of the ownership of a work of art (Amore 2015, 6). Establishing provenance involves determining the legal title of an object and verifying ownership. Fontanella (2014) writes that, ideally, one seeks to secure documentary evidence such as receipts for every occasion that an object changed hands, whether it was by gift, sale, inheritance, exchange or another form of transaction. Regrettably, there has been no consistent and regulated method for keeping such records and criminals take advantage of the difficulty in establishing solid provenance free of gaps (Amore 2015). When information is available, it is usually limited to one or two public events in the otherwise private life of an item, such as the date and place of a previous sale or its mention in a scholarly publication (Brodie 2014a). The process undertaken by buyers and sellers to ensure themselves of an object's legitimate provenance is referred to as 'due diligence' (Flynn 2016). Since most dealers do not perform adequate due diligence to determine if an object has a clean provenance (Durney and Proulx 2011, 126), knowledge of any illicit history can be avoided. Consequently, there is a risk that illicit art enters the market. The fact that many buyers are willing to accept undocumented objects further propagates corruption of the historical record (Gerstenblith 2007).

The secondary, high-end art market in Norway is relatively small. Reputable dealers are unlikely to encourage the circulation of stolen or forged objects in the market. Korsell et al. (2006) found that dealers in the Nordic countries are usually discrete for legitimate reasons (e.g., to protect their customers' financial situation). However, international research suggests that sellers may not be forthcoming with information that might prevent dealers from listing their item (Alderman 2007), and social relationships and a history of trading between dealers and collectors are used to excuse a lack of due diligence in investigating provenance when acquiring a new piece of art (Mackenzie 2011,72). In a grey market, illegitimate objects converge with legitimate ones. Without up-to-date information about stolen and fraudulent art in circulation, it is difficult to distinguish between illicit objects and objects that have entered the market through legal means.

\section{Munch: Intrinsic and Circumstantial Risk Factors}

Several sales records have been set for art by Munch in the last 20 years (Ekeseth 2016), firmly establishing his position in the international art market. In Norway, Munch dominates the list of most expensive art sold at auction. The market value of a Munch can be a powerful incentive for theft or for creating a fake provenance that presents a piece as an original. Restricting opportunities for fake art to enter the market can be even more complicated than for stolen items (Polk 1999), and it is common for fraudulent art to be wrongly considered as genuine (Amore 2015; Massy 2009). The story of Munch's art includes several instances of forgery, which started to flourish soon after his death. While most attempts are easy to expose, some are made using composition techniques associated with Munch and come with false provenance created through false sales between fictional or real persons or galleries (Pettersen 2019). In 1989, Norwegian police arrested an art dealer attempting to sell a copy of Munch's motif Starry Night with a fake certificate of authenticity created on the official papers of the Munch Museum in Oslo, Norway. The fraud was detected when the buyer contacted the museum for an export licence. The investigation revealed that the dealer had sold fake paintings through galleries and private auctions over the course of several years using various techniques of forgery (Brøyn 1993).

The difficulties in establishing the provenance of Munch's work in today's market arise in part from Germany once being his main market. In particular, there are significant gaps in the provenance of many 
artworks between 1914 and 1945. In the 1930s the Nazis labelled Munch's work as 'degenerate art'. According to art historians, some 82 pieces were confiscated from public German collections and sold to foreign dealers, with many ending up in Norwegian collections (Amundsen 2013).

The Munch Museum currently houses more than half of Munch's total production. Munch's works are also displayed across Oslo and beyond in museums, galleries, hotels, restaurants, public buildings and private residences. Critics point to a history of neglect in the safeguarding of his work, as a notable number have been lost since Munch's death in 1944. In the 1950s to 1970s, original works by Munch and other prominent artists were hanging unsecured in many public buildings around Oslo and several artworks disappeared during this period. In the museums, poor risk management combined with a lack of funding have compromised security and inadvertently facilitated several thefts (Runhovde 2020). Further, many Norwegian criminal court verdicts mention Munch artworks. In these cases, the art has been part of a criminal debt settlement, held as security for a loan or used to launder the proceeds of crime. Often, the persons convicted have attested to their involvement in the grey art market. Besides the art-related offence, these cases concern a range of additional transgressions, ${ }^{2}$ indicating that art crimes should not be seen in isolation and may be an indication of wider criminality.

The nature of the fine arts market is opaque-an insiders' world characterised by discretion and exclusivity and where the role of art dealers and auction houses sometimes extend beyond minor facilitation to active criminal support (Brodie 2014a). However, even legitimate and legal corporate practices can have harmful consequences and, thus, deserve the attention of criminologists (Passas 2005). The objective here is not to determine the guilt or criminal intent of Norwegian art dealers. Instead, drawing on interviews with dealers, museum representatives and police investigators, this article seeks to first consider what precautions dealers take to prevent illicit art from entering the market, and second to what extent circumstantial and/or intrinsic factors related to Munch's art have any regulatory effect on the trade. Findings will help to determine the ease with which illicit art can be disposed in the market and reveal the level of conscientiousness among dealers and collectors in their duty to establish sound provenance. Results will also shed light on the interface between the so-called legitimate and illegitimate art markets and indicate strategies for effective regulation.

\section{Methodology}

This article draws on qualitative research conducted in Norway between October 2018 and June 2020. Individual interviews were conducted with nine museum professionals, six high-end art dealers and auctioneers, and six police investigators, totalling 21 respondents. The museum professionals represent the Munch Museum and the National Museum in Oslo. Respondents from the art market represent major galleries and/or auction houses dealing in the secondary art market. To protect the anonymity of interviewees, all art market representatives are quoted as 'art dealer'. Recruitment of respondents took place through managers, directly through email or by snowball sampling (i.e., identifying additional respondents through existing ones) (Yin 2011, 89). Written consent was obtained in advance from all respondents by providing information about the purpose of the interview, guaranteeing anonymity and freedom to withdraw. The interviews were semi-structured in the sense that questions revolved around certain key issues including risks, provenance and discretion, in general and related to Munch specifically. A challenge in most research is to ask relevant questions and successfully identify and follow-up on key issues that arise throughout the data collection. By continually revising the interview guide, the data collection and analysis were partly concurrent. As proposed by Miles, Huberman and Saldaña (2014), this helps researchers generate strategies for collecting new and better data.

To complement the interviews, the analysis draws on international and thematically wide-ranging secondary data in the form of scientific literature, court verdicts, biographical books, one film documentary, three art exhibitions, and both newspaper articles and journalistic inquiries. The archive at the Munch Museum contains documents accumulated over the years with information about many of the crimes involving Munch's works, including correspondence from law firms and insurance companies, 
police reports, internal letters, and memos and newspaper clippings. Being granted admission, one day was spent in the archive searching for relevant information. All collected data were anonymised per agreement with the respondents, who were also given the opportunity to review quotations before the article was submitted for publication. For transparency, quotations from individual respondents are numbered to display the frequency of excerpts taken from each respondent's interview.

In terms of the literature, most publications related to thefts of Munch's art and the domestic art market are published in Norwegian. This work makes the information available to an international audience. While the researcher has tried to the best of her ability to stay true to the original meaning of interview respondents and written sources, as with all translation, there may be some unintentional loss of meaning and nuance.

Art crime is an under-researched aspect of white-collar crime (Alder and Polk 2007), partly due to difficulties in recruiting research participants (e.g., see Coslor 2010; Yates 2014). While my 'inside outsider' role (Brown 1996) as an academic civilian working in the research department of the Norwegian Police University College may have facilitated recruitment of police participants, my police affiliation could have made art dealers reluctant to participate in this study. Apart from one dealer who chose to withdraw shortly after the interview, access to dealers was straightforward and I experienced them as being genuinely interested and honest about the challenges related to their business. That said, I cannot rule out that dealers gave answers they considered were socially acceptable while omitting their own transgressions, which would threaten the validity of the data. Moreover, a qualitative study limited in time and sample size prevents generalisation of the findings in any strict sense. Instead, the goal is to consider how this research resonates with other works to suggest likelihood and probability and contribute to the growing criminological scholarship on art and antiquities crimes.

\section{Findings}

\section{Munch is a Challenging Market}

All interviewed art dealers conduct trade in art by Munch and some have specialised in this market. Asked what makes Munch attractive to dealers and collectors beyond aesthetic reasons, Art Dealer 1 explained that 'the artworks are expensive objects. Works by Munch have had a steady increase, [and] the prices do not fluctuate.' Art Dealer 2 further explained that 'Munch has an aura around him. The tragic history, it is something to talk about.' While there are major Munch collectors in Norway, Art Dealer 2 specifically highlighted the international demand for his work, resulting in a greater number of wealthy buyers. However, the dealer continued that:

Munch is a challenging market because he made so many versions of the graphic plates that interested him. So, they vary in colour, shape and depth. He made them better and better, for the most part. Therefore, you get excited when you see a new Munch.

Due to variety, making a good investment depends on knowing what you are doing. Referring to the market for Munch as 'special', Art Dealer 1 explained that while the stable value makes the art a popular investment object, the fact that prints that look identical to the untrained eye may vary considerably in worth makes it challenging for laypeople to judge the right price. Risks are especially high in the flourishing online market, where, according to Conservator 1, forgeries thrive. The archive at the Munch Museum currently lists hundreds of cases of forgery. Until 2002, the museum issued certificates of authenticity on request. People all over the world who think they are in possession of a genuine Munch still contact the museum asking for confirmation that their painting is real. 'Disappointment is virtually guaranteed', Conservator 1 commented. 
Art Dealer 3 further implied that the recorded number of criminal cases involving Munch's art have led to a tainted market:

The market for Munch is a market where various things have been going on. ... It has attracted the wrong kind of people. ... It is a market where it is easy to go wrong. The turnover has been very high. Many pieces have been on the grey market. Many pieces might lack years of documented provenance.

Establishing provenance for graphic works may be particularly challenging because Munch rarely numbered his prints. Conservator 2 explained that graphics can be printed in many impressions. Numbering each print is a way to control the amount of impressions made and serves as a contract between the artist and the buyer to indicate that the work is part of a limited edition. Indeed, it also enables monitoring of individual pieces in the market. Art Dealer 1 highlighted this risk factor when asked what might make Munch vulnerable to criminal exploitation. They explained that 'it is the lack of numbering. ... It is very difficult to build a provenance on the graphics. With the paintings there is only one, and they come in different sizes.'

Although 'writing 3/20 isn't so difficult either', according to Art Dealer 2, diminishing the significance somewhat, the lack of numbering likely forms part of what puts Munch's graphic works at risk because they can have high financial value, are difficult to trace and are, thus, easy to trade. The lack of numbering also means that no-one knows exactly how many impressions exist. A recent case illustrates how discretion in combination with lack of numbering can facilitate art crime. The case began in 2017 when the inventory of a DHL storage facility in Oslo revealed that three Munch lithographs were missing from separate storage units. In 2019, one of the missing lithographs, a Madonna, turned up in another client's unit inside the same warehouse. The first owner placed the lithograph in storage after acquiring it at auction in 2013. In 2015, the second owner bought the same lithograph from an art dealer. According to the first owner, the Madonna must have been stolen sometime prior to the second sale. A legal dispute followed between the two men, both billionaires and Munch collectors, who each claimed rightful ownership of the lithograph. A Munch expert who was present at both sales testified to having had no suspicion that the second deal concerned the same Madonna. The dealer who brokered the second sale in 2015 gained it from a contact who had acquired it from an anonymous third individual, implying the presence of what Mackenzie and Davis (2014) term a 'Janus Figure', an intermediary able to transition stolen objects from their dubious origins into the fine arts market through their connections on both sides. When asked in court why they had not questioned the provenance of the lithograph, the dealer and the second owner both stated that questions would be futile due to the customary level of discretion exercised in the market (Sæter, Gjernes and Johannessen 2020). However, the court ruled against the second owner on the grounds that he had not been diligent enough in examining the Madonna's provenance.

\section{A Relationship of Mutual Trust}

While scholars denote that protection of cultural property depends on adding the identity of buyers and sellers to public auction records to enable external supervision (Bichler, Bush and Malm 2015; Hardy 2016), interviewed dealers were adamant that privacy and confidentiality are a prerequisite for their business. Discretion is exercised to protect sellers, buyers and dealers and does not pose a problem. The dealers in this study mainly referred to their own trustworthiness as guarantee and justification for why disclosure of trade details was unnecessary. According to Art Dealer 3, 'when the trade is made through us people feel safe that everything is in order. We have a good reputation. ... It is a business that in general is very dependent on trust.' Art Dealer 4 further explained that 'the thing is people trust that what we sell is authentic and legitimate and that it can be sold legally. ... The buyer has to trust that we have done our homework.'

Interviewees described the art trade as a business greatly reliant on trust. Any critical questions prior to an acquisition is related to marketability, not mistrust or the prevention of illicit trade. While potential buyers may ask about the provenance of a painting, this is as much about wanting to know the history as 
it is authenticity, because if it comes from a renowned collection this may increase the value of the painting. Therefore, before accepting a sale, Art Dealer 4 might ask for receipts, 'because it promotes the sale'. In line with Brodie (2014b), these examples of 'autoregulation' do not imply moral agency on the part of collectors, as the intention is not to actively select well-provenanced objects with a view to minimise the harm caused by illicit trade. Instead, it is prompted by a self-interested belief that a good provenance increases the value and ensures a high resale price. Nevertheless, Art Dealer 3 conceded that 'we see that provenance matters more and more-that you can follow the history. Quality is always the most interesting, but it is a plus factor if the provenance is good.'

One example that also illustrates the connection between Munch and wartime Germany is the recent sale of Munch's Bathing Boys (1904-1905) from a Norwegian collector. In 1914, the painting was displayed in the Gurlitt Gallery3 in Berlin. From then there is a gap in the provenance until 1953 when it was bought by a Norwegian company. Since then, it has changed owner many times and been featured in major Munch exhibitions. While the painting has never been reported lost or stolen, no-one has been able to document full provenance. As Art Dealer 1 explained, several dealers have tried to build provenance but there is a gap for the war period. An attempted sale to an American museum was hindered when the museum insisted on complete provenance. Nevertheless, in July 2020, the painting was sold by Christie's in London for $£ 1.8$ million as 'property from a distinguished private Scandinavian collection', and with an historical record only going back to 1953 (Christie's 2020).

Many collectors are willing to tolerate a certain amount of illegality in the process of acquiring objects for their collections (Thompson 2015). In regard to the collectors' conscientiousness, Art Dealer 2 emphasised that:

Future financial gain comes before the law. Many think that way in Norway. ... One might say one collects art for the sake of the art, but it is financial profit that matters. Some collectors are not as inquisitive as they should be.

Whether or not driven by profit, it has been suggested that the psychology of collecting is criminogenic, in that some collectors experience a 'compulsion' to collect, often to a point that it is damaging personally and socially (Belk 1995, cited in Brodie and Proulx 2014). This would predispose them to risk-taking and render them susceptible rather than resistant to the inducement of already institutionalised malpractice (Brodie and Proulx 2014). The dealers' trust in their clients rests on them mainly acquiring objects from persons with whom they are familiar. Receipts or documentation establishing previous ownership rarely exists. Often, clients assert that the art is part of an inheritance and/or that paintings have been in their family for many years. Art Dealer 1 explained that:

Norway is a transparent country. When someone presents a painting [to us], I mostly know who they are. It is rare that someone just drops by with a painting. They might call and say that [they] own a painting by Munch, and then I go to [view it in] their home.

Art Dealers 1 and 3 both referred to Norway's status as a small and transparent country as a definitive advantage, with few people owning large collections of fine art. Operating a long-running family business, Art Dealer 3 said that '[clients] might come with a quote set by my grandfather 30 years ago. Those we sell for we have a relationship with, directly or indirectly.'

Nevertheless, Art Dealer 2 acknowledged that due diligence should be exercised regardless of familiarity with a client. Even in renowned collections acquired under expert guidance, it is possible to find one or two illegitimate works. Unknown to the collector, the copies are discovered if and when they come to sell the works.

All interviewed dealers were aware that databases citing stolen art are available for checking and most attested to using these sporadically, yet none reported to have gotten a positive hit. Art Dealer 3 explained 
that they 'have used it a little, but it is a bit random. ... It is only if we get suspicious.' However, a negative search result is no guarantee for legitimacy. Sometimes, theft from collections may not be noticed for many years. In addition, institutions may be hesitant to report theft for fear of highlighting their security problems, harming future loans (Houpt 2006) or alienating potential donors (Conklin 1994, 124). Both instances would prevent recording in a database. Asked what routines they have for due diligence, Art Dealer 4 admitted that they do not use any of the databases because:

Much of our [business] are estates and elderly people moving from a large house to an apartment, or people selling objects because they need the money. ... We note down their details and keep it for at least two weeks before it goes on auction. ... But we can't, when going to an estate, start asking, 'where did you get this from, and where did you get this from?' In 99 per cent of cases it is totally fine.

Nevertheless, in the same interview Art Dealer 4 conceded:

We, like everybody else, have experienced that objects have come in where we have checked the seller and identity and everything is in order, but then it turns out that it has been stolen and it may have been stolen many links back. Fortunately, it is not often but we have experienced it.

Other dealers reported similar experiences with regard to stolen objects or other types of ownership disputes, where they had been forced to withdraw the object from sale. Such incidents were described as highly unfortunate and potentially very damaging to a dealer's reputation.

\section{The Usual Suspects}

That said, not knowing a seller may raise suspicion and even prevent a deal from being made. Art Dealer 5 recounted an instance in 2018 when a stranger wanting to sell a Munch approached them. Due to uncertainty about the legitimacy of the work, the dealer phoned the Munch Museum to check and because legal provenance could not be established, the dealer declined. When approached by strangers, dealers attested to 'looking at the seller' before accepting an object for sale. Art Dealer 4 said that 'if intoxicated or other dubious people come knocking on our door with a Munch, then our lamp starts flashing. We consider our audience.' The dealer described how they, for example, would be more careful when contacted by foreign sellers:

We are extra careful and check who they are. If it is a gallery or a known business then it isn't a problem, but if a person from Eastern Europe should come wanting us to sell a Munch, our guard would be up.

Multiple dealers had been approached by persons featured in the media for their involvement with crime. Art Dealer 6 described how on several occasions they were approached by an individual they knew to have been convicted of art crime previously, wanting to sell lithographs by Munch. Suspicious of the person involved and their possession of the artworks, the dealer acted cautiously by contacting the police, before accepting the sale. Asked what might result in them declining a sale, Art Dealer 3 stated that:

It's dependent on gut feeling. If we sense there is something not right, we politely decline. ... It can be people walking in from the street. ... If someone pulls out two Chinese plates from a backpack, [we say no] from a fear that it is stolen. But it can also be young people having helped themselves to objects from [their parents'] home. 
Similar practices apply to other types of objects. Raising the issue of conflict antiquities, Art Dealer 6 said:

I think we would have assessed the person. If it is a former ambassador's wife whose husband has been there [in the Middle East] I guess we would have assumed that it is OK. But if someone who doesn't speak Norwegian or something ... I guess we would be a bit more sceptical and ask where it came from, and perhaps we would say no, thanks.

Several dealers indicated that the fact that they work on commission and that sellers will not receive a settlement until later when an object has been sold makes them less a target for criminals. To this, Art Dealer 6 stated that 'if they come here with stolen goods expecting fast cash then they have come to wrong place'.

\section{Discussion}

\section{Interpreting Dealers' Notions of Risk}

The majority of dealers interviewed expressed a clear intention to comply with the law and to conduct trade legitimately. While there is no indication of deliberate wrongdoing, the business practices they described suggest some degree of negligence when it comes to due diligence. Taking a favourable view, the dealers' practices may be attributed to them operating under stereotypical ideas of the type of person disposed to commit art crime and their own risk of being exploited. For example, if relying on the stereotype that criminals are generally of low social status (e.g., in terms of economic and educational attainment) (Chapman 2013), offenders in more privileged positions may be overlooked. Such notions of the typical art criminal might also be partly media driven. For example, Norwegian police have identified Eastern Europeans committing organised crime in Norway as a threat (Kripos 2012), with related crime generating significant media attention. Further, several of the Munch thefts were conducted by individuals associated with a notorious criminal gang active in the greater Oslo area from the 1990s to the early 2000s, forging a link between 'street-level criminals' and art theft (see Widerøe and Aass 2009). Psychological principles of learning, categorisation and memory predict that people are susceptible to using what they learn about one case to colour the perception of an entire category (Akalis, Banaji and Kosslyn 2008). Reading about these offenders in the press may have tainted dealers' views of art criminals in general. People may not only be unwilling to admit that they harbour stereotypes and prejudice, but also be unaware that they hold such biases (Akalis, Banaji and Kosslyn 2008). Yet, as Amore (2015) writes, art scams are increasingly convincing, and that 'while the art of art theft is said to be in the selling of the art, not the thievery, the art of art scams is in the backstory, not in the picture itself' (6-7). The best schemers take their time. Provenance may be laundered through stolen objects kept hidden until the theft is forgotten about, after which a new history is created through exhibits and agreed sales and purchases. This 'cooling-off' period may work well in directing focus away from an incident (Didriksen 2016), leading to individuals capable of such calculation escaping apprehension.

The dealers' actions may also be interpreted in a less favourable light. It may not be in the interest of dealers or collectors to ask too many questions about provenance since it could prevent them from accepting a sale. Clearly, social relationships and a history of trading between parties are used to excuse a lack of due diligence, suggesting that dealers are out of touch with the reality of the problem of illicit trade in cultural goods (Mackenzie 2011, 72). The trade in Munch is thriving and the warning from Investigator 1 that 'the criminal market is a reflection of the legal market' implies that if an artist is in high demand in the legal trade, they are similarly demanded within the illegal trade. While some may be unaware of the underlying criminal conduct that brings objects onto the art market, others are simply willing to turn a blind eye (Conklin 1994; McCalister 2005). In response to how dealers justify their lack of due diligence, Investigator 1 said that 'they wash their hands. They choose to believe that "Mrs Hansen" is OK. Perhaps it's convenient not to know so much because then business can go ahead.'

The dealers' rationalisations resemble narrative 'discourses' (Mackenzie 2005, 2011) or 'mythologies' (Elia 1995) that allow dealers and collectors to justify their actions and neutralise any allegations of harm 
that their actions might entail. Dealing in stolen art and antiquities is not a victimless crime and destroys the scientific foundation for knowledge about the past (Fincham 2009). Exploring a 'social harm' approach on the effects of modern consumerism, O'Brien (2008) writes that consumers are often unconcerned or unaware of the destruction that comes with their purchases, or perhaps they just know better than to ask. 'Like supermarket sausages they taste nice so long as you do not know how they are made' (39). Ignorance is bliss and the fetishisation of goods makes for a sense of dissociation between consumers (i.e., dealers and collectors) and the harm by which their 'products' are obtained and disposed.

\section{Awareness and Accountability}

Recalling Passas $(2005,771-772)$, while corporate practices may be legal they can have many adverse social consequences. The paradox is that when more effective regulatory action and oversight is imperative, the global neoliberal agenda promotes deregulation and a further reduction of the role of the state. It is beyond the scope of this article to discuss regulatory implications in detail, but in Norway, a recent relaxation in anti-money laundering legislation and a proposal from the government to relieve dealers from the obligation of obtaining a second-hand dealers' licence raises concern that external scrutiny of the Norwegian art trade is reducing, leaving those within the industry to regulate themselves.

Most dealers in this study expressed a commitment and intention to abide by the law, and their dependence on trust and a good reputation implies a holistic regulation strategy that provides the optimal mix of government intervention and self-regulation (e.g., as outlined within responsive regulatory theory) (Ayres and Braithwaite 1992). Importantly, some contradiction was observed regarding diffusion of responsibility for illegal trade, which was generally presented by the dealers as an aberration to otherwise legal activity. Should a dealer have traded an object that turned out to be fake or stolen, they were portrayed as much a victim as they were a perpetrator, given the harm such incidents cause to their reputation. Therefore, a formal process to ensure that dealers are held appropriately responsible for corporate misconduct and prevent them from denying their individual accountability is necessary. Developing the legal consciousness of individual collectors is equally important. Instead of assuming that there is evidence (to which they are not privy) that support a dealer's claim that an object is legitimate (Sloggett 2014), buyers should be reminded of their right and responsibility to refuse unprovenanced objects and be a pronounced target of regulation. By ruling against the second owner in the previously mentioned Madonna case, Norwegian courts have specified that failing to inquire about previous ownership is not acceptable according to the penal code. 4

Finally, the dealers in this study considered the grey market as being separate from the market in which they themselves conduct trade, and further rejected the idea of the trade as one grey market. In the words of Art Dealer 2, 'the grey market is not part of the legitimate market: it is a parallel market.' It is understandable that dealers want to distance themselves from the stigma of being associated with the grey art market. However, framing the trade not as one licit and one illicit market, but as a single trade where flows of licit and illicit objects converge, could make dealers more alert to the risks and in turn promote ethical and legal trade.

\section{Conclusion}

In Norway, the criminal targeting of Munch's art has been afforded considerable media attention and resulted in great public fervour. Acts of theft and vandalism of art have been known to enhance the viewing experience and even propagate an artist's name, leading to an increase in the demand for his or her art. It has been suggested that the significance and appeal of Munch's paintings have increased following incidents of theft (Brisman 2011; Durney and Proulx 2011), and some experts attribute Munch's position in today's international market for lithography partly to a series of thefts by a curator employed at the Munch Museum in the 1960s, causing prices to skyrocket (see Dahl 2004; Runhovde 2020). Indeed, the market for Munch is flourishing. It is also a market considered challenging and tainted with risk, yet the study finds no tangible evidence of this having any regulatory effect on the trade. While being aware of the risk, dealers do not report to exercise any particular care when trading in Munch compared to art by other 
artists. In a culture of discretion, the feasibility of disposing of illicit art by Munch through a reputable dealer must be judged achievable through perseverance and the right contacts. Every work sold that lacks provenance, even if never stolen, provides hope and encouragement to thieves and middlemen to sell objects without having to provide ownership history (Murphy et al. 2000, 66; Thompson 2015). While a stolen Munch painting would be virtually impossible to sell, the value and marketability of unnumbered graphics and drawings are attractive to those with dishonest intentions. There is a necessity for greater vigilance from those guarding the gate to the public marketplace. Norway's contemporary art dealers defend themselves by insisting that they are honest and that the grey art market is a separate enterprise to their own trade. Yet without an increase in risk awareness, accountability and transparency to illuminate the industry, it remains opaque and difficult to trust. One could say that in the dark, all art dealers are grey'.

\section{Acknowledgements}

The writing of this paper was supported by the Norwegian Research Council under Grant No. 238170 for the New Trends in Modern Policing project. I am sincerely grateful to the participants who kindly allowed me to interview them for this research. Thank you also to Professor Simon Mackenzie and Justin Gosling for their advice, and to the anonymous reviewers for providing valuable feedback.

Correspondence: Siv Rebekka Runhovde, Researcher, Norwegian Police University College, Slemdalsveien 5, 0369 Oslo, Norway. Email: siv.runhovde@phs.no

\footnotetext{
${ }^{1}$ Money laundering through art refers to both buying with tainted money and cleaning the tainted money through an art deal (van Duyne, Louwe and Soudjin 2015).

2 For example, see verdicts from Oslo District Court, TOSLO-2018-43747-3; TOSLO-2014-67448; TOSLO-2006-89948.

3 In the art world, the name Gurlitt is ill reputed. In February 2012, German officials seized 1,499 works of art in a Munich apartment belonging to Cornelius Gurlitt, including 21 works by Munch. Cornelius's father, Hildebrand Gurlitt, had been a well-known accomplice to Hitler's systematic looting of art throughout World War II. In 1914, the Gurlitt Gallery was managed by Wolfgang Gurlitt, Hildebrand Gurlitt's cousin. While it is deemed unlikely that the discovered Munch works were stolen from Jewish families and rather the result of a personal connection between Wolfgang Gurlitt and Edvard Munch, exactly how they came to be in his possession is still unclear (Henriksen 2014).

${ }^{4}$ See Sæter Gjernes and Johannessen (2020) and the verdict from Oslo District Court, TOSLO-2018-43747-3.
}

\section{References}

Akalis SA, Banaji MR and Kosslyn SM (2008) Crime alert! How thinking about a single suspect automatically shifts stereotypes toward an entire group. Du Bois Review: Social Science Research on Race 5(2): 217-233. https://doi.org/10.1017/S1742058X08080181.

Alder C and Polk K (2007) Crime in the world of art. In Pontell HN and Geis G (eds) International Handbook of White-Collar and Corporate Crime: 347-357. Boston: Springer.

Alderman KL (2007) The ethical trade in cultural property: Ethics and law in the antiquity auction industry. ILSA Journal of International \& Comparative Law 14(3): 549-570.

Amore AM (2015) The Art of the Con. The Most Notorious Fakes, Frauds and Forgeries in the Art World. New York: Palgrave Macmillan.

Amundsen B (2013) Nazistenes vanskelige forhold til Edvard Munch. [The Nazis' difficult relationship with Edvard Munch.] Forskning, 26 September. https://forskning.no/kunst-og-litteratur-kunsthistorie/nazistenesvanskelige-forhold-til-edvard-munch/608459.

Ayres I and Braithwaite J (1992) Responsive Regulation: Transcending the Deregulation Debate. New York: Oxford University Press.

Bailey M (2004) Why steal a masterpiece? Apollo Magazine 1. 
Bichler G, Bush S and Malm A (2015) Regulatory foresight: Estimating policy effects on transnational illicit markets. Journal of Contemporary Criminal Justice 31(3): 297-318. https://doi.org/10.1177/1043986215575138.

Bowman B (2008) Transnational crimes against culture: Looting at archaeological sites and the 'grey' market in antiquities. Journal of Contemporary Criminal Justice 24(3): 225-242. https://doi.org/10.1177/1043986208318210.

Brisman A (2011) Vandalizing meaning, stealing memory: Artistic, cultural, and theoretical implications of crime in galleries and museums. Critical Criminology 19(1): 15-28. https://doi.org/10.1007/s10612-010-9104-X.

Brodie D (1999) Illicit antiquities: The situation in South-East Asia. Paper presented at Art Crime Protecting Art, Protecting Artists and Protecting Consumers Conference, Australian Institute of Criminology, Sydney, 2-3 December 1999.

Brodie N (2011) Congenial bedfellows? The Academy and the antiquities trade. Journal of Contemporary Criminal Justice 27(4): 408-437. https://doi.org/10.1177/1043986211418885.

Brodie N (2014a) Auction houses and the antiquities trade. In Choulia-Kapeloni S (ed.) 3rd International Conference of Experts on the Return of Cultural Property: 71-82. Athens: Archaeological Receipts Fund.

Brodie N (2014b) Provenance and price: Autoregulation of the antiquities market? European Journal on Criminal Policy and Research 20(4): 427-444. https://doi.org/10.1007/s10610-014-9235-9.

Brodie N and Proulx BB (2014) Museum malpractice as corporate crime? The case of the J. Paul Getty Museum. Journal of Crime and Justice 37(3): 399-421. http://doi.org/10.1080/0735648X.2013.819785.

Brown J (1996) Police research: Some critical issues. In Leishman F, Loveday B and Savage SP (eds) Core Issues in Policing: 179-186. London: Longman.

Brøyn MB (1993) Falsk kunst for millioner. [Millions in fake art.] Aftenposten, 22 April.

Burnham B (1975) The Art Crisis. New York: St Martin's Press.

Chapman D (2013) Sociology and the Stereotype of the Criminal. New York: Routledge.

Chappell D and Polk K (2014) The peculiar problem of art theft. In Chappell D and Hufnagel S (eds) Contemporary Perspectives on the Detection, Investigation and Prosecution of Art Crime. Australasian, European and North American Perspectives: 37-56. Abingdon: Routledge.

Christie's (2020) ONE: A Global Sale of the 20th Century. https://www.christies.com/lotfinder/paintings/edvardmunch-badende-gutter-6269974-details.aspx?from=searchresults\&intObjectID=6269974

Conklin J (1994) Art Crime. Westport: Praeger.

Coslor E (2010) Hostile worlds and questionable speculation: Recognizing the plurality of views about art and the market. In Wood D (ed.) Economic Action in Theory and Practice: Anthropological Investigations: 209-224. Bingley: Emerald Group.

Coslor E (2016) Transparency in an opaque market: Evaluative frictions between 'thick' valuation and 'thin' price data in the art market. Accounting, Organizations and Society 50: 13-26. https://doi.org/10.1016/j.aos.2016.03.001.

Dahl HF (2004) Den største tyven. [The biggest thief.] Dagbladet. http://www.e-pages.dk/dagbladet/26118/23/.

Didriksen K (2014) De ukjente kunsttyveriene. [The unknown art thefts.] Fagbladet Miljøkrim (2). https://www.okokrim.no/de-ukjente-kunsttyveriene.416721.no.html.

Didriksen K (2016) Kultur og penger. [Culture and money.] Fagbladet Miljøkrim (1). https://www.okokrim.no/lkultur-og-pengerr.416408.no.html.

Durney M and Proulx B (2011) Art crime: A brief introduction. Crime, Law and Social Change 56(2): 115-132. https://doi.org/10.1007/s10611-011-9316-3.

Ekeseth FC (2016) Munch-verk sikter mot halv milliard. [Munch works aim for half a billion.] Dagens Næringsliv, 22 October. https://www.dn.no/kunst/edvard-munch/sotheby-s/munch-verk-sikter-mot-halv-milliard/1-15751969.

Elia RJ (1995) Conservators and unprovenanced objects: Preserving the cultural heritage or servicing the antiquities trade? In Tubb KW (ed.) Antiquities. Trade or Betrayed. Legal, Ethical \& Conservation Issues: 244-255. London: Archetype.

Fincham D (2009) The fundamental importance of archaeological context. In Charney N (ed.) Art and Crime. Exploring the Dark Side of the Art World: 3-12. Santa Barbara: Praeger.

Flynn T (2016) The art world. Compliant victim? In Tomkins A (ed.) Art Crime and Its Prevention: 19-30. London: Lund Humphries.

Fontanella MM (2014) Foreword. Collections: A Journal for Museum and Archives Professionals 10(3): 247-248. https://doi.org/10.1177/155019061401000302.

Gerstenblith P (2007) Controlling the international market in antiquities: Reducing the harm, preserving the past. Chicago Journal of International Law 8(1): 169-195.

Gruber S (2013) The fight against the illicit trade in Asian cultural artefacts: Connecting international agreements, regional co-operation, and domestic strategies. Asian Journal of International Law 3(2): 341-363. https://doi.org/10.1017/S2044251313000052. 
Hardy SA (2016) Illicit trafficking, provenance research and due diligence: The state of the art. Paris: UNESCO. http://www.unesco.org/new/fileadmin/MULTIMEDIA/HQ/CLT/pdf/Hardy 2016 UNESCO antiquities trafficki ng review materia.pdf.

Henriksen A (2014) Munch samarbeidet med omstridt samler. [Munch collaborated with controversial collector.] Aftenposten, 6 December. https://www.aftenposten.no/kultur/i/Kvq7M/munch-samarbeidet-med-omstridtsamler.

Houpt S (2006) Museum of the Missing. A History of Art Theft. New York: Sterling.

Kerr J (2016) The Securitization and Policing of Art Theft: The Case of London. Abingdon: Routledge.

Korsell L, Hedlund G, Elwér S, Vesterhav D and Heber A (2006) Cultural heritage crime: The Nordic dimension. Stockholm: Swedish National Council for Crime Prevention, Information and Publication. https://www.bra.se/bra-in-english/home/publications/archive/publications/2006-06-05-cultural-heritagecrime.html.

Kripos (2012) Trusselvurdering mobile vinningskriminelle 2012. [Threat assessment of travelling offenders committing crimes for profit.] Oslo: Kripos.

https://upload.wikimedia.org/wikipedia/commons/6/68/Trusselvurdering_mobile vinningskriminelle_2012.p df.

Mackenzie SRM (2005) Going, Going, Gone: Regulating the Market in Illicit Antiquities. Leicester: Institute of Art and Law.

Mackenzie SRM (2009) Identifying and preventing opportunities for organised crime in the international antiquities market. In Manacorda S (ed.) Organised Crime in Art and Antiquities: 41-62. Milan: International Scientific and Professional Advisory Council of United Nations Crime Prevention and Criminal Justice Programme.

Mackenzie SRM (2011) The market as criminal and criminals in the market: Reducing opportunities for organised crime in the international antiquities market. In Manacorda D and Chappell D (eds) Crime in the Art and Antiquities World: Illegal Trafficking in Cultural Property: 69-85. New York: Springer.

Mackenzie SRM and Davis T (2014) Temple looting in Cambodia: Anatomy of a statue trafficking network. British Journal of Criminology 54(5): 722-740. https://doi.org/10.1093/bjc/azu038.

Mackenzie SRM and Yates D (2017) What is grey about the 'grey market' in antiquities. In Beckert J and Dewey M (eds) The Architecture of Illegal Markets: Towards an Economic Sociology of Illegality in the Economy: 70-86. Oxford: Oxford University Press.

Mason C (2005) The Art of the Steal. Inside the Sotheby's Christie's Auction House Scandal. New York: Penguin.

Massy L (2009) The antiquity art market: Between legality and illegality. International Journal of Social Economics 35(10): 729-738. https://doi.org/10.1108/03068290810898936.

McCalister A (2005) Organized crime and the theft of Iraqi antiquities. Trends in Organized Crime 9(1): 24-37. https://doi.org/10.1007/s12117-005-1002-3.

McLeave H (2003) Rogues in the Gallery: The Modern Plague of Art Thefts. Altadena: Bitingduck Press.

Miles MB, Huberman AM and Saldaña J (2014) Qualitative Data Analysis: A Methods Sourcebook. Los Angeles: Sage.

Murphy LE, Beaudry MC, Adams REW and Brown JA (2000) Commercialization: Beyond the law or above It? Ethics and the selling of the archaeological record. In Lynott MJ and Wylie A (eds) Ethics in American Archaeology: 3841. 2nd ed. Washington: Society for American Archaeology.

O'Brien M (2008) Criminal degradation of consumer culture. In Sollund R (ed.) Global Harms. Ecological Crime and Speciesism: 35-51. New York: Nova Science.

Passas N (2005) Lawful but awful: 'Legal corporate crimes'. The Journal of Socio-Economics 34(6): 771-786. https://doi.org/10.1016/i.socec.2005.07.024.

Pettersen P (2019) Ekte eller uekte Munch? [Real of fake Munch?] In Byre E, Langbrekke J, Lerheim KE and Valla K (eds) Exit! Historier Fra Munchmuseet 1963-2019 [Exit! Stories from the Munch Museum 1963-2019]: 179-192. Oslo: Munchmuseet.

Polk K (1999) Art crime and prevention: Best practices. Presented at Art Crime Protecting Art, Protecting Artists and Protecting Consumers Conference, The Australian Institute of Criminology, Sydney, 2-3 December 1999.

Purkey H (2010) The art of money laundering. Florida Journal of International Law 22(1): 111-144.

Rostomian PC (2002) Looted art in the US market. Rutgers Law Review 55(1): 271-299.

Runhovde SR (2020) Risking Munch. The art of balancing accessibility and security in museums. Journal of Risk Research. https://doi.org/10.1080/13669877.2020.1801810.

Sæter K, Gjernes K and Johannessen SØ (2020) Den perfekte forbrytelsen: Hvem stjal Madonna? [The perfect crime: Who stole Madonna?] Dagens Næringsliv, 30 March. https://www.dn.no/magasinet/dokumentar/dhl-exel-fineart/pal-georg-gundersen/nicolai-tangen/den-perfekte-forbrytelsen-hvem-stjal-madonna/2-1-783101.

Sloggett R (2014) Considering evidence in art fraud. In Chappell D and Hufnagel S (eds) Contemporary Perspectives on the Detection, Investigation and Prosecution of Art Crime. Australasian, European and North American Perspectives: 121-134. Abingdon: Routledge. 
Sotheby's (2012) Impressionist and Modern Art Evening Sale, 2 May.

https://www.sothebys.com/en/auctions/2012/impressionist-modern-art-evening-salen08850.html?locale=en.

Sotheby's (2016) Impressionist and Modern Art Evening Sale, 14 November. https://www.sothebys.com/en/auctions/2016/impressionist-modern-art-evening-sale-n09567.html.

Thompson EL (2015) But we didn't steal it: Collectors' justifications for purchasing looted antiquities. Journal of Art Crime 13: 59-67.

van Duyne PC, Louwe L and Soudjin M (2015) Money, art and laundering: Coming to grips with the risks. In Kila JD and Balcells M (eds) Cultural Property Crime. An Overview and Analysis of Contemporary Perspectives and Trends: 79-95. Leiden: Brill.

Watson P (1997) Sotheby's: The Inside Story. London: Bloomsbury.

Widerøe RJ and Aass HP (2009) Dødsranet. David Toska og veien til Nokas. En innsideberetning fra Norges største ransmiljø. [The Deadly Robbery. David Toska and the Road to Nokas. An Inside Report from Norway's Largest Band of Robbers.] Oslo: Gyldendal.

Yates D (2014) Lies, damned lies, and archaeologists: Antiquities trafficking research as criminology and the ethics of identification. AP: Online Journal in Public Archaeology 4(2): 7-20. http://doi.org/10.23914/ap.v4i2.57.

Yin RK (2011) Qualitative Research from Start to Finish. New York: Guilford Press.

\section{Cases cited}

TOSLO-2006-89948 (26 January 2007)

TOSLO-2014-67448 (12 January 2015)

TOSLO-2018-43747-3 (1 June 2018) 